\title{
An encore collaboration between cousins: the Canadian Journal of Public Health and the Canadian Society for Epidemiology and Biostatistics
}

\author{
Une autre collaboration entre cousins : la Revue canadienne de santé publique et la Société \\ canadienne d'épidémiologie et de biostatistique
}

Jennifer Payne ${ }^{1}$ D $\cdot$ Colleen Maxwell ${ }^{2} \cdot$ Linda Dodds $^{1}$

Received: 9 August 2018 / Accepted: 30 August 2018 / Published online: 19 September 2018

(C) The Canadian Public Health Association 2018

Once again, we are excited to present a Special Section in this Journal to mark a successful and continuing collaboration between the Canadian Journal of Public Health (CJPH) and the Canadian Society for Epidemiology and Biostatistics (CSEB). As was the case approximately two years ago when these cousins last collaborated, included in this Special Section are manuscripts by authors who presented their research at the recent Biennial CSEB Conference, held in Banff, Alberta, May 30-June 2, 2017. Presenters at this conference were invited to submit a manuscript to CJPH based on their conference presentation. The submitted manuscripts underwent the normal CJPH peer-review process, with efforts made to first solicit CSEB members as reviewers.

The theme of the 2017 Biennial CSEB Conference was "Epidemiology and Biostatistics: from molecules to population." Pre-conference workshops covered an array of topics, including genetic epidemiology, software and statistical tools, the GRADE approach in evidence-based medicine, and an introduction to qualitative research. Opening parallel plenaries gave an overview of the interplay of genetic and environmental factors in the development of obesity, and highlighted the role of epidemiology in contributing to our understanding of the role of social determinants of health.

Jennifer Payne

jennifer.payne@dal.ca

Colleen Maxwell

colleen.maxwell@uwaterloo.ca

Linda Dodds

1.dodds@dal.ca

1 Dalhousie University, Halifax, NS, Canada

2 University of Waterloo, Waterloo, ON, Canada
John Last's Dictionary of Public Health defines the mission of public health as follows: "to protect, preserve and promote the health of the public. Public health is the art and science of promoting and protecting good health, preventing disease, disability, and premature death, restoring health when it is impaired, and maximizing the quality of life when health cannot be restored." (Last 2006) The mission of the CSEB is to foster and promote the two interrelated sciences of epidemiology and biostatistics to improve health and well-being through research and practice. The mission of the CSEB is certainly consistent with the mission of public health, not surprising as epidemiology is the foundational science of public health. What makes some of the CSEB papers a bit different than many of the papers in the "quantitative section" of the journal is that not all of them focus on upstream determinants of health. We argue that to be true to the definition of public health, the work of public health research, of which epidemiology research is a subset, spans the continuum from primary through tertiary prevention. In this case, all the CSEB papers are a natural fit for CJPH.

The papers published in this Special Section cover a variety of topics. Three of the papers focus on cancer epidemiology (asbestos and kidney cancer, UV tanning in adolescents, prognostic ability of TNM staging for gastric adenocarcinoma), one focuses on health services utilization (behavioural risk factors and high-cost use), and one focuses on higher risks associated with vulnerable populations (primary care utilization among the homeless). Finally, we have included a commentary on work-related musculoskeletal injuries in refugees. The breadth of topics is reflective of research in both epidemiology and public health, including a focus on vulnerable populations, high-cost users of the health system, along with more traditional topics, such as cancer epidemiology.

For many years, the topic of launching a Canadian epidemiology journal has been the subject of debate and discussion, 
but such a journal is still not viable at this point in time. Many Canadian epidemiologists may choose to publish their work in topic-specific journals, most of which are not Canadian. However, there are times when we would like to directly target a Canadian audience to reflect on the important implications of our work in a Canadian context and to share our work with Canadian colleagues.

As President of the CSEB during the 2017 Conference, Mark Oremus has expressed his support for this second collaboration between CJPH and CSEB as follows, "CSEB is pleased to collaborate with CJPH to highlight important and highquality work from Canadian-based researchers." We are hopeful that this could lead to the addition of a regular section to the journal for papers that may not fit into a traditional upstream public health framework, but nevertheless contribute to the promotion and protection of good health for Canadians.

\section{Éditorial}

Nous sommes impatients de présenter une fois de plus une rubrique spéciale marquant la collaboration fructueuse et soutenue entre la Revue canadienne de santé publique (RCSP) et la Société canadienne d'épidémiologie et de biostatistique (SCEB). La dernière collaboration entre ces « cousins » date d'il y a environ deux ans; comme à l'époque, la rubrique spéciale contient des articles d'auteurs ayant présenté leurs travaux lors du congrès biennal de la Société, dont le dernier s'est tenu à Banff (Alberta) du 30 mai au 2 juin 2017. Les orateurs et oratrices ont été invités à soumettre un manuscrit à la Revue sur la base de leurs présentations à ce congrès. Les manuscrits ont fait l'objet du processus normal d'évaluation par les pairs de la Revue, qui a d'abord essayé de recruter des membres de la Société comme évaluateurs.

L'édition 2017 du congrès biennal de la Société avait pour thème l'épidémiologie et la biostatistique : des molécules à la population. Les ateliers préparatoires ont porté sur des thèmes aussi différents que l'épidémiologie génétique, les outils logiciels et statistiques, la démarche GRADE appliquée à la médecine factuelle et une introduction à la recherche qualitative. Les plénières d'ouverture parallèles ont présenté un survol de l'action réciproque de la génétique et des facteurs environnementaux dans l'obésité et souligné comment l'épidémiologie peut nous aider à comprendre le rôle des déterminants sociaux de la santé.

Dans son dictionnaire de la santé publique, John Last définit ainsi la mission de la santé publique : [traduction] « Protéger, préserver et promouvoir la santé du public. La santé publique est l'art et la science de promouvoir et de protéger la santé, de prévenir la maladie, l'incapacité et les décès prématurés, de restaurer la santé quand elle est atteinte et de maximiser la qualité de vie quand la santé ne peut être restaurée. » (Last 2006) La SCEB a pour mission de favoriser et de promouvoir les deux sciences apparentées que sont l'épidémiologie et la biostatistique pour améliorer la santé et le bien-être par la recherche et la pratique. Cette mission est certainement conforme à celle de la santé publique, ce qui n'a rien d'étonnant sachant que l'épidémiologie est la science fondamentale de la santé publique. Ce qui distingue les communications de la Société de nombreux articles de la rubrique « Recherche quantitative » de la RCSP, c'est que tous ne portent pas sur les déterminants de la santé en amont. Nous faisons valoir que pour être fidèles à la définition de la santé publique, les travaux de la recherche en santé publique, dont la recherche épidémiologique fait partie, doivent aller de la prévention primaire à la prévention tertiaire. Sous cet angle, toutes les communications de la Société s'inscrivent naturellement dans le mandat de la Revue.

Les articles publiés dans cette rubrique spéciale abordent des sujets divers. Trois d'entre eux portent sur l'épidémiologie du cancer (l'amiante et le cancer du rein, le bronzage UV chez les adolescents, la valeur pronostique de la stadification TNM pour l'adénocarcinome gastrique), un autre sur l'utilisation des services de santé (les facteurs de risque comportementaux et l'utilisation à coût élevé), un autre encore sur les risques accrus associés aux populations vulnérables (l'utilisation des soins primaires par les sans-abri). Enfin, nous avons inclus un commentaire sur les lésions musculosquelettiques subies au travail par les réfugiés. La variété des sujets reflète celle des études en épidémiologie et en santé publique; les populations vulnérables et les utilisateurs à coût élevé du système de santé y sont traités, en plus de sujets plus classiques comme l'épidémiologie des cancers.

L'idée de lancer une revue canadienne d'épidémiologie fait l'objet de débats et d'analyses depuis de nombreuses années, mais une telle revue n'est pas encore viable. Beaucoup d'épidémiologistes canadiens choisissent de publier leurs travaux dans des revues thématiques, non canadiennes pour la plupart. Il arrive cependant que nous souhaitions nous adresser directement à un public canadien pour montrer les conséquences importantes de notre travail dans le contexte canadien et pour le présenter à nos collègues du pays.

Président de la SCEB durant le congrès 2017, Mark Oremus exprime en ces mots son appui à cette deuxième collaboration entre la RCSP et la Société : « La SCEB a le plaisir de collaborer avec la Revue canadienne de santé publique pour faire ressortir l'importance et la haute qualité des travaux des chercheurs basés au Canada ». Nous espérons que cela mènera à l'ajout d'une rubrique régulière à la Revue pour les articles qui n'entrent pas nécessairement dans le cadre classique de la santé publique, situé en amont, mais qui contribuent néanmoins à l'avancement et à la protection de la santé des Canadiennes et des Canadiens.

\section{Reference/Référence bibliographique}

Last, J. M. (Ed.). (2006). A Dictionary of Public Health. Oxford: Oxford University Press. 